THE KURUME MEDICAL JOURNAL Vol. 15, No. 3, 1968

\title{
FOUR CASES OF SEXUAL PERVERSIONS
}

\author{
AKIO HORI \\ Kyowa Hospital, Hyuga, Japan \\ TATSUO AKIMOTO \\ Department of Neuropsychiatry, Kurume University, \\ School of Medicine, Kurume, Japan
}

(Received for publication October 12, 1968)

\section{INTRODUCTION}

Since in 1916 Krafft-Ebing gave in his PSYCHOPATHIA SEXUALIS ${ }^{8}$ a comprehensive collection of sexual perversions which are anomalies in sexuality, morphological classification of their different behaviors has been attempted. However, as Nishimaru ${ }^{10}$ ) states, there has so far been no established theory as to their psychological genesis.

Particularly in this country, we have only few reports on the subject except for some publications from the side of criminal pathology. This is because, it is assumed, the cases of perversions to call on psychiatrists for diagnosis and treatment are extremely rare.

The present case report is based on the experience of the authors who, by chance, were informed of a sexual perversionists' club and has had occasion to observe some of the actual instances of polimorphic perversions. Unfortunately, however, the author could not take the detailed life-histories of these cases, since they were not the patients who came to the clinic for diagnoses.

S. Freud ${ }^{4)}$ classified the cases of sexual perversions into two categories: inversion and perversion. The four cases of the present report belong to perversion.

Case No. 1 Vinyl fetishism

Male, age 23, university student in 4 th grade.

Life-history - The patient was born near Tokyo, has one brother and two sisters. Since childhood he had the habit of bed-wetting which, notwithstanding mother's strict discipline to remedy, continued as late as he left elementary school. In those days, detergents were hardly available and the patient's mother used diaper to get over the trouble. The patient felt a mixed feeling of shame and pleasure when his mother put him a diaper and cover. It was a delightful thing to him to remember such childlike treatment given by his mother.

As he went to secondary school (old system) and began preparing for 
university entrance examination, he once felt a strong attraction to the vinyl raincoat of a foreign woman whom he saw casually in the street. Since then he began to chase with his eyes after the figures of women clad in vinyl raincoat every time it rained, he says.

By the time he entered the department of literature of a private university, vinyl raincoats came into vogue and he could see women clad in them everywhere, in the streets, in the crowded tramcars.

Soon he could no more be satisfied with seeing those raincoats from far alone, but began to be driven by an irresistible desire to touch them. So he purposefully approached women to touch vinyls. After that, he lodged in the metropolitan area by providing a reason and studied "at his will", indulging in the perverted sexual life with vinyls.

Former diseases — Nothing particular to note except bed-wetting.

Hereditary factors — Hereditary psychopatic diseases are denied.

Physical observation - Middle constitution but somewhat thin.

Hypoplasia or other degenerative syndromes in sex organ are not discernible.

Psychiatric observation - Introversive personality, with introspective tendency amounting to being masochistic.

The patient is unsociable, but show importunate affability in some respects. With his speciality in psychology, his conversation about himself is naturally rich in content. Addiction to drinking or medicine is not traceable.

The Rorschach test showed a small total number of responses, with sex responses and anatomy responses being both null, and the judgement was "somewhat melancholic".

Sexual life - He says, "I think it was quite natural for me to be attracted by the vinyl rain coat when I saw a young foreign woman clad in it for the first time".

It was true that he felt guilty which developed in him later about his inner impulse to attempt touching women's raincoats. But he did not yet think it was abnormal. He told me about his behavior, "When I find a woman to my liking clad in raincoat, I draw near and touch her from the back in a casual manner at the underpart of the waist-belt by finger tips or put the back of my hand against it. The feeling of vinyl which got soft by the woman's temperature runs through my whole body paralyzing from tiptoe to crown".

In tramcars he feels a desire of frotteurism to rub his penis against feminine rumps, but he has never done it actually because of fear.

Later he could no more be satisfied with only touching in tramcars, and he got to buy for himself women's vinyl raincoat, put it on and masturbate. By this time he began to worry about himself if he might be abnormal.

His masturbation at present goes on as follows. First, he spreads a white vinyl sheet over a mattress and lies down on it wearing a women's raincoat in nude. Then he further covers himself with a white vinyl sheet as if he put on 
a blanket. While he remains quiet, the vinyl softens by his temperature and sends out a peculiar smell which excites a pleasant feeling in him (vinyl around 1955 had a certain smell). Now he fancies himself a masochistic scene in which he himself is a woman and is tampered with in a sexual act by a woman. The sensation of pleasant sexual feeling is small in the absence of vinyl. So when he is at his parent's house, he masturbates fancying himself to be clad in vinyl. He has a fanciful desire to masturbate (not intercourse) a woman to his liking by wraping her in a vinyl sheet.

$\mathrm{He}$ is rather sorry that he cannot see much of vinyls lately (July, 1955) and is collecting raincoats of various colors, red, white, transparent, metallic, etc. He says he wants black one but he cannot get it by any means. He accepts himself as fetishist, saying, "The charm of fetish, it's a great thing!"

\section{Case No. 2 Shoe fetishism}

Male, age 32 , office worker.

Life-history - Born in uptown Tokyo, the patient was brought up evading war disasters. Since his mother died at his ten years of age, he was brought up by his father. He is the last of three brothers with no sister. He says there was nothing particular to note about his family environment. But a close hearing revealed the following memory about shoes. He did not like to put on shoes handed down from his brothers. While he did not feel any dislike to wearing second hand clothes, hat or other things, shoes were exception. They felt filthy. When wearing them, something creeped in his feet and he became so nervous that he always walked barefooted in the school.

After leaving a distinguished secondary school (old system) he entered the economics department of a certain private university.

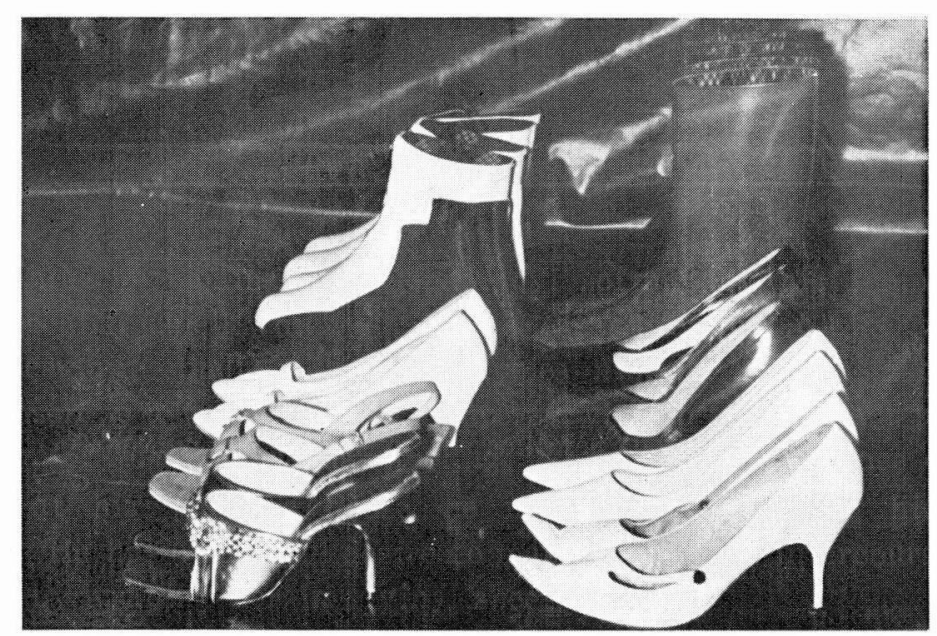

Photograph 1. Part of the collected shoes, Case No.2. 
During his secondary school and university years which included the war he had no association with woman, though he was not drafted, for he was mobilized to a factory to engage in the work of supervising the secondary school boys.

He got a job at the present company in 1948. "I can never find a slightest trace of what may be termed a sexual abnormality in myself up to the time of entering the present company", he assured. Of course he did masturbation, but there was nothing particularly fetishistic about it.

Former diseases - Hilar tuberculosis in the 4th year of secondary school.

Hereditary Factors - A brother of his father had died in a mental hospital.

Physical observation-Height $162 \mathrm{~cm}$, weight $62 \mathrm{~kg}$, somewhat piknic. No anomaly in the growth of sex organ and others.

Psychiatric observation-Extroversive personality with bright impression. A cheerful white-collar worker with a trait of sophistication, the patient is self-contemptuous about his own "sexual deviation" (his own expression). Likes drinking. No particular observation was seen in Rorschach test.

Sexual life - The patient entered the present company in 1948. From around the spring of 1950, he began to feel strangely uneasy about the sound of women's shoes walking in the building. The beating sound of high-heeled shoes was thrilling to him. "I may be tired", he thought at first, but soon he became aware that his attention was directed to the shoes themselves but not to the sound of shoes.

By this time post-war insufficiency of goods had just come to an end and commodities began to flow into market in abundance. Dresses of the girl workers of his office which was ranked among the first class companies were rapidly improving, he explains. Girls who had worn flat shoes or canvas shoes now began to turn to high-heeled shoes and their conversation focused on "how to get good high-heels with low prices". They never put off their high-heels even in office hours. In those days rubber rain shoes came into wide use and he recollects, "It was about this time that I felt a 'strange beauty' in women's shoes which seemed to 'symbolize something'".

Up to this time, he only looked at high-heeled shoes with romantic eyes. But since he got a habit just to touch them with finger tips at the time of coming to and leaving the office, the impulse seemed rapidly to take on a shadow of gloominess and become compulsive. When the entrances for men and women were separated, he ventured to buy high-heels for himself. He was so ashamed in his first shopping that he took the trouble of going as far as Kinshi-cho and lied to the sales woman in a blush, "My sister asked me to buy...". But the shoes he bought were, to his great regret, too small for him to fit, he remembers. At one time he was absorbed in rubber rain shoes, but nowadays he has returned to high-heels.

As to his sexual life, he brings the high-heel into bed with himself and 
fancies being stepped on with it or puts it in the crotch to masturbate.

At present (July, 1955) he is in marriageable age and has proposals, too. But he has had no experience of sexual intercourse with woman, and what is more, his collection of more than twenty high-heeled shoes is a resistance to his determination to marriage.

It is not that he is uninterested in women, but he feels a thrilling shiver at seeing women of beautiful legs in stockings and high-heeled shoes.

Later he handed his collection of thirty shoes over to a dilettante and went into marriage, when he was 36 . He has fathered a boy and a girl.

\section{Case No. 3 Sadism}

Male, age 52, factory manager

Life-history - The patient was born in Shikoku. After leaving a higher elementary school, he shifted from town-factory to town-factory as workman in Kobe-Osaka area and finally settled in Tokyo after the war. At present he is managing a small factory of his own. As he admits himself, he may be counted among successful men, and his factory, though small, seems to be fairly respectable.

He married early and has two boys and two girls. He has no taste for alcohol, and is hard to please at home.

Since young he has had algolagnic tendency, but it is since he entered Club A that his "nature" as sadist has manifested itself.

Former diseases - Healthy by nature.

Hereditary factors - Psychopatic diseases are denied.

Physical observation - Apparently a little fat, but the prototype seems to be leptosome. Other details are unknown, but noteworthy degenerations are expected to be null.

Psychiatric observation — Patient's calm attitude reminds a well-to-do life, with topics and conversation suggestive of high intelligence. One can hardly think he was educated only in higher elementary school. He may be a hard worker, but lacks stiffness characteristic of such personality. His generosity is rather suggestive of a second generation manager.

For some reasons we could not perform the personality test.

Sexual life — Since childhood he felt thrill in the "torture scene" of marionette show. When he was about to leave the higher elementary school, he remembers, he secretly desired to torment a girl of his age to his heart's content. When he was working in small businesses shifting from job to job, he used up most of his salary to see the torture scenes of stage and film (in those days festival shows contained ill-treating scenes beyond our imagination today).

When he was married he could not do such thing toward his wife and he contented himself with fancying ill-treating scenes at the time of intercourse. In his fantasy the form of torture was the same as in his childhood, while the 
object woman was now a grown-up, who with disorderly hair in a strip of loincloth was beaten to his heart's content with a split bamboo.

On one occasion he entered Club A, the place where dilettantes congregated and sado-masochistic shows were staged and the members participated in the plays.

He could take this occasion to materialize his fantasy for the first time in his life. During the first year he played entirely according to the aforesaid fancy. But since then his "taste" has changed and his play at present takes the following form.

The woman clad in a slip on a white brassière and corset and wearing stockings and high-heeled shoes is tied to a pole. He himself in women's black brassière, corset, stockings and high-heeled shoes approaches the woman with an electric whip in his hand, while the woman is expected to look at him with a constant smile on her face. His face is masked by a black hood with only openings at eyes. He stands in front of the woman and her face turns from a smile to a beaming look. At this moment he puts the electric whip against her. Though it is not electrified she is expected to collapse as if dead. Meanwhile she cannot utter a voice or laugh. He is satisfied with this and does not always masturbate. However, if he does, he does in front of the woman and she is forced to look at his sex organ in the act. Since he entered the club he has never beaten the woman. He says that a thought of screaming or blooding is only disagreeable.

\section{Case No. 4 Masochism}

Male, age 56, company director

Life-history - The patient was born in a family of landowner in a small town of North Kanto district. Since sometime before entering an elementary school, he said, he began to delight in receiving clyster. $\mathrm{He}$ was graduated from the literary course of a national university, entered a semigovernment enterprise and went as far as Korea and Manchuria. At present he is a director of two or three private corporations.

He does not like to tell about his family affairs and the environment of his growth.

Former diseases - Since childhood the patient has had feeble stomach and intestines. But this is not a disease, he says.

Hereditary factors - Hereditary psychiatric diseases are denied.

Physical observation - Typical executive-type, round face, thin hair, piknic.

Psychiatric observation - Apparently well-bred. Though he had the experience of heavy drinking when young, he now drinks only in a measure agreeable to keep social relations.

For some reasons, personality test was not carried out.

Sexual life - In his childhood he used to have his mother give him clyster 
because of some disease which he cannot remember now. In those days, he says, the clyster which was a long stick of candy was softened on a fire and was put into the anus.

Throughout his secondary school and university he could not get rid of the habit acquired in his childhood and continued to stimulate the anus himself by inserting such things as fountain pen and candy sticks.

The habit continued after he got job and when he came to know of the "fig-mark enema", he exclusively used this one in lavatory.

He first controlled the oncoming urge of evacuation caused by the enema and then gave expulsion at a stroke, which was most pleasurable, and his childish fantasy of being put under the spell of a witch was still the same as in his childhood.

After the war when he settled in Tokyo, the habit still continued and at one time he had a strong desire to give clyster to a woman worker of his company, but he has never done it because he was afraid of losing social status through such act.

Since he came to know Club A, he has been content to have a place here to satisfy what he calls his "inside taste". His only fear has been that this might be known to his acquaintances and would deprive him of his position and job, bringing a catastroph to his family.

His play at present proceeds as follows. He lies on a bed wearing brassière, corset and stockings. The woman gives him fig-mark clyster. He controls the urge to evacuate as far as possible and finally gives way as the woman receives the evacuation onto a pot. Meanwhile the woman is expected to look at his face, constantly rubbing his abdomen. He on the other hand fancies receiving the "magic enema" which is a sort of enema containing secret Chinese medicines of North Manchurian origin. He says that this has the effect to "purify and regenerate" his body. He is completely satisfied with this act and usually does not go so far as masturbation. However, in the case of masturbation, the woman who gave him clyster must take the part of massaging.

By the way he once gave clyster to a woman in Club A, but the result was so different from what he had fancied that he shrank before the smell and filth of excreting feces, he remarked with a bitter smile. In the past he felt attraction to white satin 'tabi' (Japanese socks) and to bath-marks of crepe. But as the dresses of post-war women workers became luxurious, he came to be attracted to underwears of mannequins in department stores and became corset mania, he added.

\section{DISCUSSION}

Two cases of fetishisms and a case each of sadism and masochism were described in relation to their symptomatic generation and evolution and their status quo. 
As to the generation mechanism of sexual perversions, we have as yet no established theory. Psychology proposes the theory of congenital and acquired characteristics $^{2)}$, and the physiology of brain attempts interpretation from the standpoint of conditioned reflex ${ }^{6)}{ }^{7}{ }^{11}$, while psychoanalytical explanations are given in terms of such concepts as conflicts in childhood, regression into various stages of sexual development and symbolism ${ }^{4}$.

Now, the four cases presented here are not those who came for treatment nor those who came to ask help for a ruined social life brought about by their sexual habits. All of them are well adapted to social life, without ever causing a catastrophe in their every day life in spite of their abnormalities. They are all married and are extremely fearful that their abnormal acts might destroy their married life, ruin the family and in the end they would be buried in oblivion from the society. They are fully aware of their sexual abnormalities and are good critics of themselves.

Freud states that development of ego starts with bodily interest. In cases also it is conceivable that sexual abnormalities observed in these patients may be explained by the fixation of libido in the early dominant erogenous zone.

Let us consider the vinyl fetishism of Case No.1. As regards the garments and accessories, Schilder ${ }^{15)}$ states that garments are the extension of bodyimage and the garments which a person wears are dissolved in his body-image. According to Garma ${ }^{5)}$, garments are the covering to protect the external body, symbolizing the amnion or other maternal protective envelope. In this respect, the vinyl in this case may seem to symbolize the amnion or may be considered as fixated to the experience of diaper-cover which the patient's mother applied to him when he wetted the bed till late in his boyhood. In relation to the patient's statement that he feels utmost peace and ease and experiences orgasm when covered in vinyl, we may refer to kaiser ${ }^{9)}$ who maintains from the point of view of body-image that an experience of isolated or changed body appears at the time of orgasm and the feeling of body boundary becomes obscured.

Moreover, in the case of neurosis, as he states, the patient does not obtain orgasm, in order to protect the body-image from changing. It is probable that such protective reaction is produced in the present case of vinyl fetishism, so that he is released to obtain orgasm only when covered in vinyl.

While in the first example patient's interest was directed principally toward somato sensory motor, the interest of the patient in the second case of fetishisms tends to be more aesthetic. In his case libido toward women is replaced by women's shoes. For him shoes and women are equivalent, with beauty in the mean. Now if the element of beauty is too strong, it tends to curb the sexual drive in the admirer. Thus beauty obstructs the attempt to approach the loved and makes it infeasible.

Although beauty does not give complete satisfaction of the lust, it gives peacefulness and ease. Perhaps his sexual drive was put under inhibition which 
caused to replace the sex organ or female with shoes. By way of substituting shoes for sex organ he became aesthetic and could dissolve the uneasiness toward his urging sex drive. For him shoes are equivalent to sex organ and the object is beauty. Thus he is enabled to abandon his own sexual drive by submitting to beauty and obtain peacefulness and ease, even to become alien toward women.

As for the third and fourth examples, they were tentatively classified as sadism and masochism. While they shows some quantitative difference in their behaviors, it is difficult to divide them uniquely into sadist and masochist. They have aspects in common and represent one and the other sides of a sexuality.

In these two cases we see transvestisms, in which the patient wears women's underwear and ident!fies himself with the object woman. Man can easily take the parts of other individual's body into his own body-image and conversely put his own body-image into the object's, thereby identifying his own body with the object's. Schilder calls this "appersonization".

The wearing of brassière, corset, stockings and high-heeled shoes in these examples may otherwise be regarded as playing the role of protective garments which Wilhelm Reich ${ }^{14}$ ) calls body armor, building up a body-image of omnipotence. This may be interpreted by Federn's ${ }^{3)}$ theory that one's ego itself undergoes a change with the change in his bodily ego-feeling.

In the next place, we may note the existence of a magical and archaic way of thinking in these two cases. This may be understood if we consider the algolagnia traceable in both cases. Schilder, namely, states that a magical way of thinking manifests itself in man when he has a sensation of pain. This is related to the circumstance that a stinging pain induces anal erotic and sadistic regressions and leads to regression into the early dominant erogenous zone.

Now let us consider the relation between sado-masochistic plays and sexual offences. Is it true that sadistic plays too far advanced tend to risk sadistic offences? Some people say that algolagnic tendency which is present in everybody to some extent is improperly called abnormal and, infact, it is not abnormal unless it manifests itself in offensive acts. It should benoted here that the difference between sadistic offence and sexual sadism ${ }^{12)}{ }^{13)}$, is not quantitative but entirely qualitative. The former represents insatiable lust of destruction in which there is no sympathetic feeling of coexistence between the destroyer and the destroyed, while in the latter there exists a love between man and woman. As a matter of course this is a childish, egocentric love which is not elevated to the height of adult love feeling. But the "feeling of co-living between the two partners based on the implicit understanding of existing love" is indispensable here, to say the least. The fact that the victim in Case No. 2 was forced to smile constantly may serve to illustrate the necessity of the existence of love in sexual sadism.

With regard to the absolute necessity of love in the world of sado-maso- 
chists, we may cite a passage from Medard Boss ${ }^{11}$ who argues from the standpoint of existentialism, "In order that he (Ehrlich Klotz, a sado-masochist) may come out of his "KLOTZ-WELT" and "Das Liebend-in der Welt-Sein Können" be opened before him, it was absolutely necessary for the partner to have a deep sensation of joy in being beaten as well as in beating. The woman had to "rejoice in the torment" so that the sexual experience may be completed"

In conclusion, it must be added that the impression of Club $\mathrm{A}$ is widely different from what might be expected of a "Cuoriosity Hunting Club".

In effect, it has no element of obscenity, and the perverted acts there are performed in a most solemn and grave manner according to a fixed formalism which is elevated to the height of a ritual being presented in a most delicate and strict choice of tastes. The impressions from those acts which were rather like those from rituals reminded me of the symptomatic behaviors observable in a sort of compulsive neurotics.

Discussions of perversions given above are of general and superficial character and are in need of deeper analysis. It will be noted that none of the four cases mentioned were subjected to treatment for particular reasons.

\section{REFERENCES}

1) Boss, M. : Der Sexuellen Perversionen. Verlag Hans Huber, Bern, 1947.

2) Elis, H. : Studies in the Psychology of Sex. F. A. Davis Co., Philadelphia, 1928.

3 ) Federn, P. : Some Variation in Ego Feeling. Int. J. Psychoanl, 7, 434-444, 1926.

4) Freud, S. : Gesammelte Schriften Von Signund Freud. Internationaler Psychoanalytischer Verlag, 1925.

5 ) Garma, A. : The Origin of Clothes. Psychoan, Quart., 18, 173-190, 1949.

6) Hess, W. R. : Psychologie in Biologischer Sicht. Georg Thieme Verlag. Stuttgart, 1962.

7) Hayashi, T. : Study of Conditioned Reflex (Application). Hyoron-sha, Tokyo, 1950.

8) Krafft-Ebing : Psychopathia Sexualis. Ferdinand-Enke Verlag, Stuttgart, 1924.

9) KAiser, S. : Body Ego during Orgasm. Psychoan. Quart,, 21, 153-166, 1952.

10) Nishimaru, S. : Psychology of Abnormal Sexual Impulse. Japan Medical Journal Co., Ltd. Tokyo, 1950.

11) Pierre Naville : La Psychologie Science du Comportement. Librairie Gallimard, Paris, 1942.

12) Podolsky, Edw. : Sexual Sudism. Epic Publishing Co., New York, 1961.

13) Podolsky, Edw. : Sexual Masochism. Epic Publishing Co., New York, 1961.

14) Reich, W. : Charakteranalyse. (im Selbstverlag des Verfassers), 1933.

15) Schilder, P. : The Image and Appearance of the Human Body. Kegan, Paul, Trench and Trubner Co., London, 1950. 